\title{
Cooperative Breeding by the Galápagos Mockingbird, Nesomimus parvulus
}

\author{
Margaret F. Kinnaird and Peter R. Grant \\ Division of Biological Sciences, The University of Michigan, Ann Arbor, Michigan 48109, USA
}

Received July 7, 1981 / Accepted October 1, 1981

Summary. The costs and benefits of helping behavior were analyzed for 36 pairs of the Galápagos mockingbird, Nesomimus parvulus, and their associates. Helping at the nest is usually done by sons or males suspected to be offspring of the breeders. Costs and benefits to breeders were assessed by comparison of pairs with and without helpers, and costs and benefits to helpers were assessed by comparison of birds which help and those which establish themselves as novice breeders.

Helping behavior benefits breeders by increasing fledging success and by reducing the adult energy load in territory defense and feeding of nestlings. Breeders assisted by helpers may also benefit by decreased nest predation. Helpers enhance their inclusive fitness by helping, and gain directly by increasing their chances of securing a territory. Helpers do not appear to gain any fitness advantage from the experience of assisting, nor do they increase their survivorship by remaining on natal territory.

Ecological and demographic features such as saturated territories and low territory turn-over rates due to high adult survival may be primarily responsible for the evolution of the helping behavior, with kinselection reinforcing it. Associated features of this system are a male-biased population sex ratio, a greater energetic benefit to breeding males than to breeding females in having helpers, earlier dispersal and breeding by females than by males, and much more frequent helping by males than by females. These are interpreted as consequences of brothersister aggression that indirectly minimizes the chances of inbreeding.

\section{Introduction}

Helping behavior is defined for birds as the participation in the breeding activities by individuals other than the genetic parents (after Skutch 1961). Analysis of the advantages of helping behavior to donors (helpers) and recipients (breeders) has been of interest to evolutionary biologists because helping behavior can be used to investigate the applicability of the concept of inclusive fitness (Hamilton 1964). Many argue (see review by Brown 1978) that helping behavior may increase the individual fitness of the recipient breeding pair and/or the inclusive fitness of the non-breeding donor.

Inclusive fitness, or the representation of an individual's genes in present and following generations (Hamilton 1964), has two components, direct fitness and indirect fitness (Brown 1980, Brown and Brown 1981). Direct fitness is mediated through the genes in an individual's own offspring. Indirect fitness is mediated through copies of the genes in the offspring of other, usually related, individuals. Recipient fitness increases directly through: (1) an increase in fledging success (Brown 1970, 1974, 1978 a; Brown and Brown 1981; Emlen 1981; Fry 1972; Gaston 1978; Ligon and Ligon 1979; Orians et al. 1977; Parry 1973; Ridpath 1972; Woolfenden 1975); (2) a greater recipient survival when donors reduce the adult energy load in nest building (Dow 1978; King 1980), territorial defense (Brown and Balda 1977; Gaston 1978) or feeding nestlings (Brown 1978a; Parry 1973; Stallcup and Woolfenden 1978); (3) an ability to occupy a larger and/or better territory (Brown and Balda 1977; Gaston 1976) and (4) increased protection against predators (Emlen 1978; Woolfenden 1975). A decrease in recipient inclusive fitness has been suggested by Zahavi (1974) on the basis of a possibly greater attraction of predators to nests with helpers and to competition for food between helpers and offspring.

Increases in the fitness of the donor are more difficult to identify. Benefits may occur either directly by individual selection or indirectly through kin selection. Direct benefits enhance the probability that the 
donor's genes will be passed on to its own future offspring. This probability has been sugested to increase with: (1) experience gained in caring for other individuals' young (Brown 1978a; Emlen 1978); (2) decreased dispersal-related mortality (Rowley 1965); (3) territory inheritance (Rowley 1965, 1978; Woolfenden 1975, 1976; Woolfenden and Fitzpatrick 1978) and (4) possible reciprocation of the helping behavior by the aided offspring (Brown 1970, 1975, 1978a; Emlen 1978; Hamilton 1964; Ligon and Ligon 1978; Maynard Smith and Ridpath 1972; Ricklefs 1975; Reyer 1980). Indirect gains may occur through kin selection if the helpers are close relatives of breeders whose reproductive success is increased by the helping (Brown 1970, 1975, 1978; Emlen 1978; Hamilton 1964; Maynard Smith and Ridpath 1972; Ricklefs 1975; Reyer 1980).

An ideal system for investigating the possible advantages of helping behavior is provided by the Galápagos mockingbird (Nesomimus parvulus). Grant and Grant (1979) documented the occurrence of helpers at the nest in this species. Some of the helpers were known to be offspring of the breeding pairs and others were suspected to be close kin. Because of the tameness and open nests of the mockingbirds, care of young by different group members can be easily quantified, behavior can be readily observed, and all reproductive efforts can be monitored.

The initial study of Grant and Grant (1979) was restricted to a single breeding season. The purpose of this paper is to explore the consequences of helping in a three-year period, and to use this information, cast in a cost/benefit framework, to answer questions about the evolution and maintenance of co-operative breeding in this species.

\section{Materials and Methods}

Isla Genovesa is at the northeast extremity of the Galápagos archipelago and is one of the most isolated of the 16 major islands (Black 1974). It has an area of $17.35 \mathrm{~km}^{2}$ and maximum elevation of $76 \mathrm{~m}$ (Wiggins and Porter 1971). Grant and Grant (1979) studied mockingbirds here from 19 January to 2 May 1978 . The present study was conducted from 1 March to 22 March in 1979 and from 10 January until 12 May in 1980 in the same study area, which is approximately one square $\mathrm{km}$ area immediately inland from the centrally located 'tourist-landing' beach (see Grant and Grant 1979). These periods fall under the wet, hot season (Grant and Boag 1980). A rain gauge at the top of the beach was checked daily.

Mockingbirds were captured in mist nets or small wire cages. The cages were baited with crackers and peanut butter, bananas, or sausages. Birds were weighed with Pesola ${ }^{\circledR}$ spring balances and measured in the manner described for Geospiza spp. in Grant et al. (1975). Sex was determined by adult wing length (from wrist to tip of longest primary; males $\geqq 115 \mathrm{~mm}$ and females $\leqq 113 \mathrm{~mm}$, Grant and Grant 1979) and additionally by behavior at the nest. Young could not be sexed until they were at least two months old. Two colored plastic or celluloid bands were placed on their legs for later recognition. Territories were mapped by repeatedly recording positions of singing males or positions of aggressive bouts between members of neighboring territories.

Nests were checked every second or third day. Nestlings were weighed, measured, and banded on the eighth day after the day of hatching. Visits to the nests by breeders and helpers, the number and frequency of prey items delivered to the nest and social interactions were recorded during one-hour watches at a distance of three to five meters from the nest during 07:00-12:00 and 14:0017:00 h. Each nest was watched at least once during all hours of the designated periods. Altogether 42 nests were watched every third day from time of discovery until the fledging of the last young. Nineteen additional nests were watched less often.

For all observations away from the immediate nest site, such as foraging behavior, an upper limit of five minutes per bird per day was set in order not to bias data with frequently encountered individuals. Dispersal distances were measured for birds who survived from one breeding season to the next. These dispersal distances were measured in units of $50 \mathrm{~m}$ from either the natal area for juveniles or the center of the territory of the previous year for adults. Location of territorial disputes, initiators of disputes, and composition and dominance hierarchy of the members of each group were recorded for all territorial bouts.

\section{Results}

\section{Benefits to the Breeder}

a) Reproductive Success. In Table 1 we have listed the 1980 breeding season status of birds of known age. All females aged two years or more were breeding and all males of that age were breeding or helping, whereas some younger birds were doing neither. Comparable data from 1978 and 1979 are not included because ages of many birds were unknown then. However, the sexes of the helpers from all three years were known. Of thirty birds which helped at a total of $24(36 \%)$ nests, only two were females. Because the clutches attended by the two females were either large (5 eggs) or oversized ( 7 eggs), it is possible that

Table 1. Status of birds of three different age catagories during the breeding season of 1980

\begin{tabular}{|c|c|c|c|c|c|}
\hline \multirow[t]{2}{*}{ Age } & \multirow[t]{2}{*}{$n$} & \multirow[t]{2}{*}{ Breeding } & \multirow[t]{2}{*}{ Helping } & \multicolumn{2}{|c|}{ Neither but still alive } \\
\hline & & & & On territory & Off territory \\
\hline \multicolumn{6}{|l|}{1 year } \\
\hline Males & 9 & 0 & 5 & 3 & 1 \\
\hline Females & 7 & $4^{a}$ & 0 & 0 & 3 \\
\hline \multicolumn{6}{|l|}{2 years } \\
\hline Males & 6 & 3 & 3 & 0 & 0 \\
\hline Females & 3 & 3 & 0 & 0 & 0 \\
\hline \multicolumn{6}{|l|}{3 years } \\
\hline Males & 12 & $10^{b}$ & $2^{b}$ & 0 & 0 \\
\hline Females & 4 & 4 & 0 & 0 & 0 \\
\hline
\end{tabular}

a Three females bred during the laying of the first clutches. The fourth made her first breeding attempt at the time of the second clutches

b One male bred and simultaneously helped at a neighboring nest 
Table 2. Reproductive success of breeders with and without helpers

\begin{tabular}{|c|c|c|c|c|c|c|c|c|}
\hline & \multicolumn{2}{|l|}{1978} & \multicolumn{2}{|l|}{1979} & \multicolumn{2}{|l|}{1980} & \multicolumn{2}{|l|}{ Total } \\
\hline & Helped & Not Helped & Helped & Not Helped & Helped & Not Helped & Helped & Not Helped \\
\hline Number of nests & 7 & 22 & 4 & 2 & 13 & 19 & 24 & 43 \\
\hline Number of eggs & 23 & 58 & $?$ & $?$ & 49 & 71 & - & - \\
\hline Number of eggs hatched $=\mathrm{A}$ & 22 & 38 & 16 & 5 & 38 & 58 & 76 & 101 \\
\hline Number of nestlings fledged $=B$ & 19 & 26 & 14 & 3 & 28 & 40 & 61 & 69 \\
\hline Fledging success $=(100) \mathrm{B} / \mathrm{A}$ & 86 & 68 & 87 & 6 & 74 & 69 & 80 & 68 \\
\hline Number of fledglings per nest & 2.7 & 1.2 & 3.5 & 1.5 & 2.2 & 2.0 & 2.5 & 1.6 \\
\hline Number of fledglings per individual & 0.9 & 0.8 & 0.9 & 0.8 & 0.6 & 1.0 & 0.8 & 0.9 \\
\hline
\end{tabular}

the helpers had laid one or more eggs and that their 'helping' behavior was in fact parental behavior, especially as both females incubated. All males but one were the largest of their brood, and no more than one per brood helped their parents.

A convenient measure of reproductive success is the proportion of eggs hatched which gave rise to fledglings. Since age and previous breeding experience are known to affect reproductive success in many bird species (Greenwood et al. 1979; Lack 1968), we first tested for a difference in the reproductive success between two and three-year-old female mockingbird breeders using a chi-square contingency test; one out of three females in each category was aided by a helper. No significant difference was found $\left(\chi_{1}^{2}=1.0\right.$, $P>0.1, n=22$ nestlings). Using the same proportions we tested for a difference between one-year-old female breeders and all older breeding females. One-year-old breeders reared significantly fewer young than older birds $\left(\chi_{1}^{2}=5.71, P<0.025, n=33\right)$. For this reason data from three nests of one-year-old female breeders have been omitted henceforth from the calculations of reproductive success. Using the same test procedure, we compared fledging success for three pairs where the female had past experience with three pairs where the female was a novice and older than one year. Fledging success (which averaged 2.3 and 2.6 fledglings/pair for experienced and inexperienced females respectively) was not found to increase significantly with experience $\left(\chi_{1}^{2}=0.22, P>0.1\right)$.

Data on reproductive success have been split into two groups to compare breeders with and without helpers (Table 2): we assume that nests without helpers did not receive rare and undetected visits from helpers outside our observation periods. No difference was found in the number of eggs laid between pairs with and without helpers in both 1978 and 1980 $\left(t_{23}=0.84\right.$ for $1978, t_{28}=0.05$ for $1980, P>0.1$ in each case). Hatching success is measured by the number of eggs hatched as a proportion of the number of eggs laid. There were no differences in hatching success between helped and unhelped pairs in 1978 or $1980\left(\chi_{1}^{2}=0.23\right.$ for $1978, P>0.1, n=88$; $\chi_{1}^{2}=1.67$ for $\left.1980, P>0.1, n=113\right)$. Data from the breeding season of 1979 were not tested because they were incomplete.

Table 2 compares fledging success for the two groups over three breeding seasons. Fledging success was higher from nests with helpers than from nests without helpers in all three years, but in no one year was the difference statistically significant $\left(\chi_{1}^{2}=2.39\right.$ for $1978, \chi_{1}^{2}=2.0$ for $1979, \chi_{1}^{2}=2.1$ for $1980, P>0.1$ in each case). However, the difference between groups is significant when the data for the three years are combined $\left(\chi_{1}^{2}=6.14, P<0.01\right)$. Fledging success did not increase with group size. In 1980, pairs with one helper $(n=7)$ fledged on the average 2.4 offspring per nest, and pairs assisted by two helpers $(n=4)$ fledged only 2.2 offspring per nest. Two nests where the female breeder was chased away by an outside pair are not included in the calculations.

The mean number of fledglings produced per nest was significantly higher in groups with helpers than in groups without helpers for 1978 and $1979\left(t_{27}=\right.$ $7.05, P<0.01$, and $t_{4}=3.70, P<0.05$, respectively) but not for $1980\left(t_{30}=0.33, P>0.1\right)$. For the three years combined, the difference is significant $\left(t_{65}=2.8, P<\right.$ 0.01 ). On a per capita basis, the mean number of offspring attributable to each individual on territory was almost equal for pairs with helpers and without helpers for all three years separately or combined (Table 2).

Another measure of reproductive success is fledgling survival over one year. Table 3 shows the number of young mockingbirds fledged in 1978 and 1979, and resighted in the breeding season of the following year. These resightings are considered estimates of survival. They are minimum estimates because some birds may have dispersed out of the study area. However, we searched territories adjoining the study area and never sighted a banded bird. Therefore, we assume the dispersal factor to be insignificant when estimating survival. While there is a suggestion in the 1978 data that juvenile survival was higher from 
Table 3. Fledgling survival for pairs with and without helpers

\begin{tabular}{|c|c|c|c|c|c|c|}
\hline & \multicolumn{2}{|l|}{1978} & \multicolumn{2}{|l|}{1979} & \multicolumn{2}{|l|}{ Total } \\
\hline & Helped & Not Helped & Helped & Not Helped & Helped & Not Helped \\
\hline Number of fledglings & 14 & 13 & 14 & 4 & 28 & 17 \\
\hline $\begin{array}{l}\text { Fledglings resighted } \\
\text { after one year }\end{array}$ & 8 & 7 & 3 & 1 & 11 & 7 \\
\hline Percent survival & 57 & 54 & 21 & 25 & 39 & 41 \\
\hline
\end{tabular}

Table 4. Average number of feeding visits to the nest per hour by breeders and helpers in 1980

\begin{tabular}{|c|c|c|c|c|c|c|c|}
\hline \multirow[t]{3}{*}{ Pair } & \multirow{3}{*}{$\begin{array}{l}\text { Number } \\
\text { of } \\
\text { watches }\end{array}$} & \multicolumn{6}{|c|}{ Number of hourly visits } \\
\hline & & \multicolumn{3}{|c|}{ Parents } & \multicolumn{2}{|c|}{ Helpers } & \multirow{2}{*}{$\begin{array}{l}\text { Total/ } \\
\text { nest }\end{array}$} \\
\hline & & Male & Female & Total & Male $_{1}$ & $\mathrm{Male}_{2}$ & \\
\hline 1 & 4 & 3 & 5 & 8 & 6 & 4 & 18 \\
\hline 2 & 4 & 5 & 3 & 8 & 5 & 4 & 17 \\
\hline 3 & 4 & 5 & 7 & 12 & 4 & & 16 \\
\hline 4 & 10 & 2 & 9 & 11 & 5 & 1 & 17 \\
\hline 5 & 5 & 7 & 7 & 14 & & & 14 \\
\hline 6 & 4 & 5 & 6 & 11 & & & 10 \\
\hline 7 & 5 & 7 & 9 & 16 & & & 16 \\
\hline 8 & 5 & 10 & 6 & 16 & & & 16 \\
\hline 9 & 5 & 14 & 5 & 9 & & & 10 \\
\hline
\end{tabular}

nest with helpers than from those without, the 1979 data show no such tendency. Sample sizes for each year are small, but even when 1978 and 1979 data are combined there is no significant difference in fledgling survival $\left(\chi_{1}^{2}=0.27, P>0.1, n=17\right)$.

Thus the benefit to breeders of having one or more helpers is an increase in fledging success.

b) Adult Survival. Banded, breeding adults which were sighted from one breeding season to the next were known to have survived. Those which were not resighted were considered not to have survived. Adult mockingbirds appear to be very sedentary once they have established themselves on a territory as a breeding pair and tend not to leave unless one of the pair has died. This is demonstrated by five of the eight pairs studies during the first field season in 1978 which were still on territory in 1980. After the death of the male breeder of one of these five pairs in 1980 , the breeding female disappeared from the area. Such sedentary habits, together with the fact that no banded adult has ever been sighed outside the study area, suggest that the survival figure is a valid one.

Annual adult survival from one breeding season to the next was high. Nine of the 10 banded breeding adults from the 1978 breeding season were resighted in 1979. Twenty-three of the 25 adults known to be breeding in 1979 season survived to 1980 . Thus 23 of 26 banded adults that bred in either 1978 or 1979 were resighted one year after their breeding at- tempts. Sixteen of these 26 individuals were helped during their breeding attempts and 14 of these survived. The remaining 10 breeders were unassisted and nine survived from one breeding season to the next. There is no significant difference between these proportions $\left(\chi_{1}^{2}=0.05, P>0.1, n=26\right)$. Therefore annual survival of adults is not detectably increased by help received in raising their offspring.

c) Nest Building. Contributions to nest building by helpers appear to be small. Data on nest building were not gathered in a quantitative manner, but some generalizations can be made from observations. Helpers were only seen bringing materials to eight of the 20 nests known to have helpers in 1980 . These deliveries were rare and in most cases carried out when the dominant male was absent.

d) Feeding of Nestlings. Table 4 summarizes food delivery to nine nests of comparable brood size (3-4 nestlings) and roughly similar age of nestlings (age 5 to 10 days) from the 1980 breeding season. Four of these nests belonged to pairs with helpers and five to pairs without helpers. Brood size and nestling age did not differ systematically between these two groups. At all nests but two, the female fed the nestlings more frequently than the breeding male. Helpers tended to bring food as frequently as the breeding male.

Visits by fathers were reduced in the presence of helpers. This is shown by a significant difference in the number of hourly feeding visits by fathers with and without helpers (Mann-Whitney $U_{4,5}=0, P<$ 0.01 ). It suggests a decrease in energy expended by breeding males for the feeding of nestlings when assisted by helpers. There is no difference in number of hourly visits by the mother at nests with and without helpers $\left(U_{4,5}=8.5, P>0.1\right)$. The total number of hourly visits by all visitors was higher at nests with helpers than at nests without helpers $\left(U_{4,5}=2.0\right.$, $P=0.032$, one-tailed). The same characteristics were shown in 1978 (Grant and Grant 1979), but the sample of observations was smaller and not amenable to statistical analysis.

e) Territorial Defense. Galápagos mockingbirds live on year-round, all-purpose (Brown 1974) territories. 
The birds are highly territorial and overtly aggressive. A ritualized display which we refer to as 'flick-fighting' was described in detail by Venables (1940) and again by Hailman (1960) as territorial dancing. Flickfighting occurs at territory boundaries or less frequently within a territory when an alien mockingbird has trespassed. The display occasionally breaks into actual fighting, or grappling, between individuals of opposing sides. Given the assumption that the overall costs of territorial defense remain constant regardless of the number of participants per group, which we regard as approximately correct, a high percentage of flick-fight participation by helpers should reduce the breeders' costs of territorial defense. In a sample of 173 observations of groups with helpers involved in flick-fights, the proportions of contests in which male, female or helper participated were $0.49,0.42$ and 0.64 respectively. These proportions differ significantly from a $1: 1: 1$ ratio $\left(\chi_{1}^{2}=8.2, P<0.02\right)$. Comparable proportions for breeders without helpers $(n=31$ observations) are 0.97 (males) and 0.54 (females). We further devised an index of aggression by dividing the number of times individuals of a particular status grappled with a member of another group by the number of flick-flights in which individuals of that status participated. By this index helpers $(0.11)$ were more aggressive than the breeders, while male breeders (0.07) were more aggressive than female breeders (0.04). Therefore, to the extent that our starting assumption is correct, helpers reduce the breeders' energetic costs of territorial defense.

There may be more than an energetic cost in territorial defense. In June 1980 a two year old helper with a broken tibiotarsus was captured. The most likely explanation for the break is that it was sustained in a grappling flight.

f) Territory Size. Daily sightings of pairs or groups were plotted on a gridded map to give an estimate of territory boundaries. Territory sizes were then estimated from this grid system by counting the number of partial or whole grid squares within each territory boundary. Territories occupied by more than two birds $\left(\bar{x} \pm \bar{x} ; 4650.0 \pm 365.4 \mathrm{~m}^{2}\right)$ were significantly larger than territories occupied by single pairs $\left(3833.3 \pm 274.6 ; t_{34}=1.74, P<0.05\right.$ by a one-tailed test). We estimated territory size on a per capita basis by dividing the number of individuals per territory into the overall territory size and recalculating means. Territory size per capita is significantly higher for individuals in pairs $(1916.6 \pm 137.3)$ than for birds in groups $\left(1397.5 \pm 138.6 ; t_{34}=2.44, P<0.05\right.$, onetailed). Territory quality is perhaps a more important measure than territory size, but meaningful data on this aspect are lacking and would be extremely difficult to obtain. g) Predation. Egg or nestling loss due to predation was low. Only seven of $78(9.0 \%)$ first and second brood nests in 1978 and 1980 combined suffered predation. Six of these predated nests belonged to pairs without helpers and one belonged to a pair with a helper. There is no significant difference in the frequency of predation between nests attended by helpers and those not attended by helpers $\left(\chi_{1}^{2}=0.7, P>\right.$ 0.1 . However, the presence of helpers at the nest may cause a decreased loss due to predation which is not shown here because of the low frequency of overall nest predation. We do not know who the predators were, but suspect they may have been mockingbirds and owls (see also Grant and Grant 1979).

\section{Direct Benefits to the Helper}

a) Experience Gain. Helpers may benefit in their own future breeding attempts by gaining experience in the rearing of other birds' young. Only two of six novice male mockingbirds were known to breed without having helped first, so statistical comparisons are not possible. However, the number of young fledged by these two novice males was higher than the sample of four novice breeding males with past helping experience ( $\bar{x}$ fledglings/nest $=3.0$ and 1.75 respectively). This result may be biased by the predation of one nest of the experienced group. Even when this nest is eliminated the mean fledglings/nest of males with helper experience (2.3) is still lower than the average for those without helping experience.

It was shown earlier that experienced pairs produced no more young than inexperienced pairs. If breeding experience cannot be shown to be beneficial, the effect of helping experience would be even more difficult to demonstrate. Therefore, helping experience is apparently not an important direct variable in reproductive success.

b) Decreased Dispersal-Related Mortality. We compared distances dispersed by 9 male and 9 female juveniles approximately one year after fledging. On average females $(81 \mathrm{~m})$ had dispersed farther than males $(28 \mathrm{~m})$. A Kolmogorov-Smirnov two-sample test does not show these samples of male and female dispersal distances to come from significantly different frequency distributions $\left(K_{\mathrm{D}}=4.0, P>0.05\right)$. However, the sample sizes of individuals and comparable dispersal intervals $(n=5)$ are small, so small but real differences may exist.

A netting census was performed in known mockingbird territories three or four months after fledging in 1979 and 1980. This permitted the trapping and sexing of banded and unbanded juveniles known to be off their natal territory. The proportion of females 
Table 5. Locations of mockingbirds of known age

\begin{tabular}{|c|c|c|c|c|c|c|}
\hline & \multicolumn{2}{|c|}{ 1-year-olds } & \multicolumn{2}{|c|}{ 2-year-olds } & \multicolumn{2}{|c|}{$>3$-year-olds } \\
\hline & $\begin{array}{l}\text { Male } \\
n=12\end{array}$ & $\begin{array}{l}\text { Female } \\
n=8\end{array}$ & $\begin{array}{l}\text { Male } \\
n=6\end{array}$ & $\begin{array}{l}\text { Female } \\
n=3\end{array}$ & $\begin{array}{l}\text { Male } \\
n=12\end{array}$ & $\begin{array}{l}\text { Female } \\
n=4\end{array}$ \\
\hline $\begin{array}{l}\text { Off natal } \\
\text { territory }\end{array}$ & $17 \%$ & $63 \%$ & $50 \%$ & $100 \%$ & $83 \%$ & $100 \%$ \\
\hline $\begin{array}{l}\text { On natal } \\
\text { territory }\end{array}$ & $83 \%$ & $37 \%$ & $50 \%$ & $0 \%$ & $17 \%$ & $0 \%$ \\
\hline
\end{tabular}

$(n=25)$ was significantly higher than the proportion of males $(n=9)\left(\chi_{1}^{2}=7.5, P<0.01\right)$. This suggests that females are dispersing earlier and/or farther than males. The suggestion is supported by data in Table 5 , which show that in each of the first three years of life a higher proportion of females than males are observed off the natal territory.

By dispersing more, females may be more likely to die in their first year than are the more sedentary males. However, the proportions of 1978 and 1979 juvenile males $(n=21)$ and females $(n=29)$ which were resighted either on or off natal territory approximately one year after fledging were not significantly different $\left(\chi_{1}^{2}=0.98, P>0.1\right)$. As with the adults, we are assuming here that frequency of dispersal in both sexes is relatively low beyond the study area where juveniles would not be resighted. Therefore there is no evidence that juvenile males experience lower mortality by staying at home.

However, at some stage in the mockingbird life history, a sex difference in mortality occurs if movement of birds out of the study area can be assumed to be approximately the same as movement in. Differential mortality is suggested by a $1.38: 1$ male-biased sex ratio in the total adult and subadult 1980 banded population. Assuming the primary sex ratio is $1: 1$, differential mortality could occur in the nest, after fledging or among adults. Because we were unable to sex birds under two months of age, the first hypothesis is impossible to test. However, we were able to test for a difference in male-female adult survival. The proportions of 46 males and 31 females that were resighted and known to survive from one breeding season to the next were compared. Adult males were found to have a significantly higher survival that adult females $\left(\chi_{1}^{2}=5.2, P<0.02\right)$. One possible explanation for this differential adult mortality is that the females breed earlier and would be expected to die earlier, especially if they experience greater physiological stress in breeding. They may be also more vulnerable to predators (owls).

c) Territory Inheritance. The fact that territory boundaries were contiguous and that all vegetated areas were held by mockingbirds suggests a "saturation' of territories in all three years, at least in the study area and probably over almost all of the island. Therefore the chance for a helper or novice to secure a territory and gain breeding status depends largely on how many breeding males die and leave a vacated territory. When this study was begun in 1978 only eight breeding territories were investigated. These territories have been monitored for three seasons yielding a total of 24 territory-years. During this time four new males became established as breeders within these territories; three had previously been seen to help their parents and the fourth was suspected of doing so. They became established in three ways: by inheriting the territory after the disappearance of the breeding male $(n=1)$, by occupying a vacated neighboring territory $(n=1)$, and by taking over an expanded section of the territory which they had helped their parents to secure $(n=2)$. An unknown number of wandering males, some banded, were potential competitors for these territories. These observations, although few, suggest that because the vacancies were filled only by previous local helpers, the acquisition of a local territory may be a direct benefit gained by helping.

\section{Indirect Benefits to the Helper}

a) Indirect Inclusive Fitness. Based on theoretical work by Hamilton (1964), Brown (1975, 1978a), West Eberhard (1975) and Emlen (1978) defined the criterion for an increase in inclusive fitness from helping. This criterion is met when $\left(N_{2}-N_{1} / H\right) r_{\mathrm{hr}}>$ $N_{0} r_{\text {ho }}$, where $N_{2}=$ the average number of young fledged by a helped pair, $N_{1}=$ the average number of young produced by pairs without helpers, $H=$ average number of helpers in those groups with helpers, $r_{\mathrm{hr}}=$ relatedness of helpers to recipient offspring, $N_{0}=$ the number of offspring produced by a pair where at least one individual is a novice breeder and $r_{\mathrm{ho}}=$ relatedness of helpers to own offspring.

Table 6 shows the $N_{0}, N_{1}$, and $N_{2}$ values for each breeding season. It is impossible to calculate $N_{0}$ for seasons previous to 1980 because breeding histories were not known for any of the pairs. Emlen (1978) suggests $N_{1}$ may be used as an estimator of the $N_{0}$ value. We consider this to be a reasonable assumption, and used the $N_{1}$ value as an approximation of $N_{0}$ for 1978 and 1979. This should cause the $N_{0}$ value to be inflated if anything and make it less likely for us to observe inclusive fitness benefits. In 1980, when we were able to estimate them separately, $N_{0}$ and $N_{1}$ values were almost the same (Table 6).

Table 7 shows that the indirect fitness component of young males was increased by helping in 1978 and 1979 , but to a very small extent, and that it 
Table 6. Reproductive success values for three breeding seasons. $N_{0}$ average number of offspring produced by a pair where at least one individual is a novice breeder; $N_{1}$ average number of offspring fledged by pairs without helpers; $N_{2}$ average number of offspring fledged by pairs with helpers; $\bar{H}$ average number of helpers present at those nests with helpers

\begin{tabular}{lllll}
\hline & $N_{0}$ & $N_{1}$ & $N_{2}$ & $\bar{H}$ \\
\hline 1978 & 1.2 & 1.2 & 2.7 & 1.2 \\
1979 & 1.5 & 1.5 & 3.5 & 1.2 \\
1980 & 2.2 & 2.1 & 2.2 & 1.4 \\
Total & 1.3 & 1.6 & 2.5 & 1.3 \\
\hline
\end{tabular}

Table 7. Application of reproductive data to Emlen's kin selection model. $\left(N_{2}-N_{1} / \bar{H}\right) r_{\mathbf{h r}}$ the annual contribution to inclusive fitness by remaining a helper; $N_{0} r_{\text {ho }}$ the annual contributions to inclusive fitness achieved by an individual breeding on its own

\begin{tabular}{llll}
\hline & $\left(N_{2}-N_{1} / \bar{H}\right) r_{\mathrm{hr}}$ & $N_{0} r_{\mathrm{ho}}$ & $\left(N_{2}-H_{1} / \bar{H}\right) r_{\mathrm{hr}}>N_{\mathrm{o}} r_{\mathrm{ho}}$ \\
\hline 1978 & $(2.7-1.2 / 1 / 2) 0.5$ & $1.2(0.5)$ & $0.6>0.59$ \\
1979 & $(3.5-1.5 / 1.2) 0.5$ & $1.5(0.5)$ & $0.8>0.75$ \\
1980 & $(2.2-2.1 / 1.4) 0.5$ & $2.2(0.5)$ & $0.04 \ngtr 1.1$ \\
Total & $(2.5-1.6 / 1 / 3) 0.5$ & $1.6(0.5)$ & $0.75 \ngtr 0.78$ \\
\hline
\end{tabular}

was not increased in 1980 or overall. However the relative value of helping is greatly underestimated. Because of ecological and demographic constraints, breeding opporunities for the novice male are low. The value of breeding, rather than helping, has to be discounted by the degree of diffuculty in securing both a territory and a mate. With so many unmeasured variables determining the discount, we have been unable to revise the calculations. Nevertheless it seems safe to conclude that, for the three years combined, helping enhanced the indirect component of the fitness of the helper.

\section{Discussion}

The original evolution of helping behavior in mockingbirds probably took place in the ancestors on the mainland. The mainland descendents (Mimus longicaudatus), like the island descendants, associate in groups of more than two birds in the breeding season (Marchant 1960; Grant and Grant 1979). The question for Galápagos mockingbirds, then, is what maintains the helping behavior?

For a helping behavior to be maintained in a population, benefits to both breeder and helper should exceed any costs to the breeder when the extra individual(s) remains on territory, and any costs experienced by the donor when not breeding. Mockingbird pairs with helpers experience an increase in fledging success and a decrease in energy expenditure in feeding nestlings, defending territories, and possibly to a smaller degree, nest building. This apparently results from energy expended by the helpers during territorial conflicts, food delivery and the gathering of materials for nest building. An increased reproductive success yields a potential increase in the direct fitness of the breeder. Lowered time and energy costs in nest building, feeding and defence could also, but apparently did not, result in a greater survival for assisted birds or their offspring and more breeding attempts. However, the results do not suggest negative effects such as increased conspicuousness to predators or competition for food resources due to helper presence.

These results are similar to those of other studies of co-operatively breeding species in showing that breeders with helpers experienced higher reproductive success than breeders without helpers. The Galápagos mockingbird appears to be most similar to the Florida scrub jay (Aphelocoma coerulescens) in this respect, as well as in social structure and dynamics. Over a 10-year period Woolfenden (1981) found that pairs of jays with helpers $(n=141)$ fledged on average 2.3 young per nest, whereas pairs without helpers ( $n=$ 125) fledged only 1.5. Comparable figures for the mockingbird are 2.5 and 1.6 (Table 2). Consistent associations between helper presence and high reproductive success among several species suggest a cause and affect relationship, but correlated variables such as habitat quality can render this questionable. However, Brown and Brown (1981) experimentally removed helpers of the Grey-crowned babbler (Potamostomus temporalis) to test the hypothesis that helpers cause the elevation in reproductive success, and found the hypothesis to be supported. This strengthens the inferences made from correlation or association data alone as in our study.

Brown and Brown (1981, p. 245) wrote "The questions for the field biologist are as follows: Does helping raise the direct fitness of recipients? If so, then how much, and by what mechanism?" For mockingbirds on I. Genovesa the answers are yes, by almost one nestling per nest, possibly through an overall increase in the rate of delivery of food to the nestlings.

To understand the maintenance of helping behaviour, the field biologist also needs to answer the additional following questions: do the helpers gain by helping, and if so does the gain exceed that to be expected from breeding? For Galápagos mockingbirds the first answer is that they do gain an indirect fitness increment through helping relatives raise offspring. The second question is more difficult to answer, but in two out of the three years the benefits from helping exceeded the potential benefits from breeding. The difficulty resides in estimating the opportunities available for breeding, and at present we have no quantitative measure of such opportunities. 
To judge from the distribution of territories, opportunities appear to be low. So even though the potential fitness gain by breeding may be higher than the gain in helping relatives, as appeared to be the case in 1980 , that potential can be realized by very few individuals. Thus we doubt that mockingbirds are behaving altruistically when helping, in the sense of giving up a greater potential benefit by helping instead of breeding. Since it is difficult for young male mockingbirds to realize their breeding potential, they do not actually give it up. Instead, we suggest, mockingbirds are behaving selfishly, and by doing so maximize their inclusive fitness.

Many authors (see e.g. references in Koenig and Pitelka 1981) have stressed that the evolution of cooperative breeding is favored in those species which 'saturate' their habitat. Low annual mortality among yearly resident territorial breeders releases few spaces for new breeders to establish themselves each year. These circumstances select against major commitments to dispersal and independent breeding by young male birds even after they have reached maturity. They do select for residence on natal territories and occasional forays outside in search of vacant territories. Galápagos mockingbirds resemble other territorial co-operative breeders in these respects. They also agree with a specific prediction of the Koenig and Pitelka (1981) habitat model that reproductive success on a per capita basis is no larger in groups than in pairs.

Thus, to answer the question posed at the beginning of the Discussion, helping behavior in these mockingbirds is maintained by the benefits experienced by both donors and recipients. If there is genetic variation underlying propensity to help it is subject to individual selection. Inasmuch as donor and recipient are usually closely related, kin selection can operate also.

The remaining question we address is why helping is almost exclusively a male characteristic. We expect helping to be predominantly a male trait, given the bias in the sex ratio, but it is not obvious why females usually do not help at all in their first year, i.e. before they have the opportunity to breed. We suggest the answer may lie in behavior selected to minimize the chances of inbreeding. One of the benefits of staying on territory as a helper is enhancement of the likelihood of later securing part or all of that territory. This was observed in three cases. The enhancement is further suggested by the fact that breeders with helpers had larger territories than breeders without helpers; territory size in the Florida scrub jay increases as family size increases, and a helper often secures a segment of the territory (Woolfenden 1981), although whether its role as helper is crucial to securing it is an unanswered question (Brown 1978 b). Be- tween-sex aggression among siblings determines which sex secures the territory. Male mockingbirds are always dominant to female siblings, so a male secures a part of the natal territory and females disperse off territory. We suggest that females help rarely, even though they might be able to increase their inclusive fitness indirectly by doing so, primarily because of the aggression from their brothers. Gaston (1978) and Greenwood (1980) have similarly stressed the connection between the breeding system and a sex difference in dispersal tendencies.

Sibling aggression has some self-reinforcing effects upon the different reproductive tactics of males and females. Helpers reduce the cost to breeding males of feeding their young. Perhaps in consequence of this saving, adult males survive longer than females. For breeding birds, females are therefore the limiting sex (Trivers 1972) and their opportunities for breeding are greater than the opportunities for males. This promotes early dispersal and early breeding in females, and diminishes the advantages to females of staying on territory to help at the nest. The relative lack of aggressiveness in females may facilitate their acceptance on alien territories.

These ideas are somewhat speculative but similar to those expressed by Woolfenden (1981) from a more solid data base to explain the social system of Florida scrub jays. We do not know if there is inbreeding depression. A brother-sister mating in 1980 yielded three fledglings, which shows only that many data are needed to detect a reproductive disadvantage to inbreeding if it exists. We do not know whether one or both parents also discourage helping by daughters. We do not know why adult females do not reduce their feeding visits to the nest when aided by helpers. Perhaps the adult male, which does reduce its visits, is not completely confident of paternity (cf. Alexander 1974). The largest gap in our knowledge is the set of rules that governs the transition of status from family member on natal territory to independent breeder. A long-term study is needed to supply the missing information.

Acknowledgements. This study was carricd out with the support and permission of the Dirección General Forestal del Ecuador, Galápagos National Park Service, the Charles Darwin Foundation and the Charles Darwin Research Station. We thank D. Schluter, S. Harcourt, H. Vargas and T.C. Will for field assistance and R.L. Curry, R. Dale, B.R. Grant, N. Grant, B. Hazlett, S. Millington, R.B. Payne, J. Powell, T.D. Price, B. Rathcke and D. Schluter for discussing the work and reading the manuscript.

\section{References}

Alexander RD (1974) The evolution of social behavior. Annu Rev Ecol Syst 5:325-383

Black J (1974) Galápagos: archipielago de Colon. Imprenta Europa, Quito, Ecuador

Brown JL (1970) Cooperative breeding and altruistic behavior in the Mexican jay, Aphelocoma ultramarina. Anim Behav $18: 366-378$ 
Brown JL (1974) Alternate routes to sociality in jays - with a theory for the evolution of altruism and communal breeding. Am Zool 14:63-80

Brown JL (1975) Evolution of behaviour. Norton, New York

Brown JL (1978a) Avian communal breeding systems. Annu Rev Ecol Syst 9:123-156

Brown JL (1978 b) Avian heirs of territory. Bio Science 28:750-752

Brown JL (1980) Fitness in complex avian social systems. In: Markl $H$ (ed) Evolution of social behavior: Hypotheses and empirical tests. Verlag Chemie, Weinheim, pp 115-128

Brown JL, Balda RP (1977) The relationship of habitat quality to group size in Hall's babbler, Pomatostomus halli. Condor $79: 312-320$

Brown JL, Brown ER (1981) Kin selection and individual selection in babblers. In: Alexander RD, Tinkle DW (eds) Natural selection and social behavior. Chiron, Newton, pp 244-256

Dow DD (1978) Breeding biology and development of the young of Manorina melanocaphala, a communally breeding honeyeater. Emu 78:207-227

Emlen ST (1978) The evolution of cooperative breeding in birds. In: Krebs JR, Davies NB (eds) Behavioural ecology: an evolutionary approach. Sinauer, Sunderland, MA, pp 245-281

Emlen ST (1981) Altruism, kinship, and reciprocation in the whitefronted bee eater. In: Alexander RD, Tinkle DW (eds) Natural selection and social behavior. Chiron, Newton, pp 217-230

Fry CH (1972) The social organization of bee aeters (Meropidae) and cooperative breeding in hot climate birds. Ibis $114: 1-14$

Gaston AJ (1978) The evolution of group teritorial behavior and cooperative breeding. Am Nat 112:101-110

Grant PR, Boag PT (1980) Rainfall on the Galápagos and the demography of Darwin's Finches. Auk 97:227-244

Grant PR, Grant N (1979) Breeding and feeding of the Galapagos mockingbird, Nesomimus parvulus. Auk 96:723-736

Grant PR, Smith JNM, Grant BR, Abbott IJ, Abbott LK (1975) Finch numbers, owl predation and plant dispersal on Isla Daphne Major, Galápagos. Oceologia (Berl) 19:239-257

Greenwood PJ (1980) Mating systems, philopatry and dispersal in birds and mammals. Anim Behav 28:1140-1162

Greenwood PJ, Harvey PH, Perrins CM (1979) The role of dispersal in the Great tit: the causes, consequences and heritability of natal dispersal. J Anim Ecol 48:123-142

Hailman JP (1960) Hostile dancing and fall territory of a colorbanded mockingbird. Condor 62:464-468

Hamilton WD (1964) The genetical evolution of social behavior I and II. $J$ Theor Biol 7:1-52

King BR (1980) Social organization and behavior of the Greycrowned babbler, Pomatostomus temporalis. Emu 80:59-76

Koenig WD, Pitelka FA (1981) Ecological factors and kin selection in the evolution of cooperative breeding in birds. In: Alexander RD, Tinkle DW (eds) Natural selection and social behavior. Chiron, Newton, pp 261-280
Lack D (1968) Ecological adaptations for breeding in birds. Methuen, London

Ligon JD, Ligon SH (1978) Communal breeding in green woodhoopoes as a case for reciprocity. Nature 276:496-498

Ligon JD, Ligon SH. (1979) The communal social system of the green woodhoopoe in Kenya. Living Bird 17:159-197

Marchant S (1960) The breeding of some S.W. Ecuadorian birds. Ibis 102:349-381, 584-599

Maynard Smith J, Ridpath MG (1972) Wife sharing in the Tasmanian native hen Tribonyx mortierii: a case of kin selection? Am Nat 106:447-452

Orians GH, Orians CE, Orians KJ (1977) Helpers at the nest in some Argentine Blackbirds. In: Stonehouse B, Perrins CM (eds) Evolutionary ecology. Macmillan, London, pp 137-151

Parry V (1973) The auxilliary social system and its effects on territory and breeding in Kookaburras. Emu 73:81-100

Reyer H-U (1980) Flexible helper structure as an ecological adaptation in the Pied kingfisher. Behav Ecol Sociobiol 6:219-227

Ricklefs RE (1975) The evolution of co-operative breeding in birds. Ibis 117:531-534

Ridpath MG (1972) The Tasmanian native hen, Tribonyx mortierii II The individual, the group and the population. CSIRO Wildl Res 17:53-90

Rowley I (1965) Life history of the Superb blue wren. Emu $64: 251-297$

Rowley I (1978) Communal activities among white-winged choughs Corcorax melanorhamphus. Ibis 120:178

Skutch AF (1961) Helpers among birds. Condor 63:198-226

Stallcup JA, Woolfenden GE (1978) Family status and contribution to breeding by Florida scrub jays. Anim Behav 26:1144 1156

Trivers RL (1972) Parental investment and sexual selection. In: Campbel1, B (ed) Sexual selection and the descent of man. Aldine, Chicago, pp 136-179

Venables LSV (1940) Nesting behavior of the Galápapos Mockingbirds. Ibis $4: 629-639$

West Eberhard M (1975) The evolution of social behavior by kin selection. Q Rev Biol 50:1-34

Wiggins IL, Porter DM (1971) Flora of the Galápagos Islands. Stanford University Press, Stanford, CA

Woolfenden GE (1975) Florida scrub jay helpers at the nest. Auk 92:1-15

Woolfenden GE (1976) Co-operative breeding in American birds. Proc XVI Int Ornithol Congr, pp 674-684

Woolfenden GE (1981) Selfish behavior by Florida Scrub Jay helpers. In: Alexander RD, Tinkle DW (eds) Natural selection and social behavior. Chiron, Newton, pp 257-261

Woolfenden GE, Fitzpatrick JW (1978) The inheritance of territory in group-breeding birds. BioScience 28:104-108

Zahavi A (1974) Communal nesting by the Arabian babbler. Ibis $116: 84-87$ 